\title{
Film-Screen Radiographic Artefacts: A Paradigm Shift in Classification
}

\author{
T. Adejoh ${ }^{*}$, S. W. I. Onwuzu'², F. B. Nkubli3 ${ }^{3}$ N. C. Ikegwuonu ${ }^{3}$ \\ ${ }^{1}$ Radiology Department, Nnamdi Azikiwe University Teaching Hospital, Nnewi, Nigeria \\ ${ }^{2}$ Medical Imaging Unit, Department of Medical Centre, University of Nigeria, Nsukka, Nigeria \\ ${ }^{3}$ Medical Radiography Department, University of Maiduguri, Maiduguri, Nigeria \\ Email: adtoms@yahoo.com, warriciwene@gmail.com, activeflavour@yahoo.com, \\ ikegwuonunwamaka@gmail.com
}

Received 16 June 2014; revised 16 July 2014; accepted 15 August 2014

Copyright (C) 2014 by authors and Scientific Research Publishing Inc.

This work is licensed under the Creative Commons Attribution International License (CC BY).

http://creativecommons.org/licenses/by/4.0/

c) (i) Open Access

\begin{abstract}
Objective: To propose a new method of classifying film-screen radiographic artefacts. Methodology: A prospective study was carried out at the Radiology Department of a University Teaching Hospital in Nigeria between June, 2011 and June 2013. Radiographs were assessed with the aid of a viewing box for artefacts which were arranged according to prior classifications by other researchers. They were subsequently grouped according to pre-arranged format into the new classification. Result: The following groups were observed: packaging (dark), procedure (greyscale), patient (greyscale), pre-processor (dark), processor (greyscale) and post-processor (greyscale). Conclusion: Classification of artefacts based on appearance and stage of introduction into film is easier to understand and remember.
\end{abstract}

\section{Keywords}

Artefacts, Greyscale, Classification

\section{Introduction}

It is well documented in literature that all radiologists make mistakes when interpreting imaging studies [1]. Such mistakes may arise from radiographic artefacts which are structures not naturally present in living tissue but of which an authentic image appears on a radiograph [2]. They mask true abnormalities, create pseudolesions [3] which are distracting and compromise accurate diagnoses [4].

Radiographic films are processed with the automatic or manual processors. It is documented that radiographic artefacts occur more commonly in the Darkroom [2] and with manual than the automatic processor [5]. Despite

*Corresponding author.

How to cite this paper: Adejoh, T., Onwuzu, S.W.I., Nkubli, F.B. and Ikegwuonu, N.C. (2014) Film-Screen Radiographic Artefacts: A Paradigm Shift in Classification. Open Journal of Medical Imaging, 4, 108-111.

http://dx.doi.org/10.4236/ojmi.2014.43015 
the introduction of digital radiography which has supplanted film-screen systems, artefacts have still not been eliminated but only reduced [6]. In order to avoid misinterpretation, recognizing artefacts and understanding their physico-technical background are of great importance in imaging [7].

A review of literature reveals artefactual classification based on causative agents although artefacts can also be categorized by the mechanism of interference with image acquisition, processing, or display [8]. In a work done using mammography, a closely related modality to X-Ray, Van Ongeval et al. [7] classified artefacts as patient-related, technologist-related, machine-related, processing-related and viewing conditions-related. In another similar work four categories were discussed: machine, patient, technologist and processor [3]. Minus and plus density as a means of describing artefacts has also been used by Akinola, et al. [2].

The weakness of the earlier classifications above lies in their inability to indicate specifically how and when artefacts are introduced into radiographs. The classification we propose is a condensation of stages of the radiographic process as well as specific artefactual activities and agents.

\section{Materials and Method}

This was a prospective study carried out in the Radiology Department of a University Teaching Hospital in Nigeria between June 2011 and June 2013. Formula was used to establish a minimum sample size of 400 radiographs with artefacts. Using purposive sampling method, radiographs produced between June 2011 and June 2013 which were archived and viewed by the researchers using a $100 \times 50 \mathrm{~cm}$ giant viewing box. Artefactual ones were subsequently separated from those free of artefacts. The artefactual radiographs were further scrutinized to determine the specific artefacts on them. This scrutiny was achieved by observation of each stage of the radiographic cycle as well as darkroom simulations of artefacts when ambiguity was high. The number of trends were subsequently differentiated. Simple statistical tools were used to calculate central tendencies and frequency.

\section{Results}

Table 1 shows the characteristics of the isolated artefacts. A description of each artefactual trend, their appearance as well as specific causes are given. The frequency of occurrence is also given. Multiple-dispersed dots (35\%) caused by dirty intensifying screens are the most common while grid lines $(0.8 \%)$ caused by immobile or wrong surface of stationary grid has the least frequency. The proposed classification is shown in Table 2.

Table 1. Characteristics of isolated artefacts.

\begin{tabular}{|c|c|c|c|c|c|c|c|}
\hline S/no & Type of artefacts & Description & Appearance & Trend & Specific cause (s) & Frequency & $\%$ \\
\hline 1. & Dispersed dots & Tiny, irregular bright spots & Greyscale & Procedure & Dirty intensifying screens & 140 & 35.0 \\
\hline 2. & $\begin{array}{l}\text { Kinks; } \\
\text { crescent-shaped }\end{array}$ & Dark crescent-shaped marks & Dark & Pre-processor & $\begin{array}{l}\text { Film bending during } \\
\text { loading into cassette }\end{array}$ & 65 & 16.0 \\
\hline 3. & Scratches & Thin, irregular lines & Greyscale & Post-processor & $\begin{array}{l}\text { Abrasion of radiograph } \\
\text { with hard surface }\end{array}$ & 62 & 15.5 \\
\hline 4. & Fogging; uneven & $\begin{array}{l}\text { Black irregular borders } \\
\text { on film }\end{array}$ & Dark & Pre-processor & Light leak into Cassette & 55 & 14.0 \\
\hline 5. & Water marks & $\begin{array}{l}\text { Minus density, irregular, } \\
\text { thick tattoos }\end{array}$ & Greyscale & processor & $\begin{array}{l}2 \text { films Stuck together in } \\
\text { processor }\end{array}$ & 21 & 5.3 \\
\hline 6. & Roller marks & $\begin{array}{l}\text { Uniform, straight-line, } \\
\text { edge-to-edge strips }\end{array}$ & Greyscale & processor & $\begin{array}{l}\text { Roller friction with film } \\
\text { or paused film transport }\end{array}$ & 13 & 3.2 \\
\hline 7. & Grease stains & $\begin{array}{l}\text { Minus density finger } \\
\text { marks }\end{array}$ & Greyscale & Post-processor & $\begin{array}{l}\text { Poor handling during } \\
\text { sorting }\end{array}$ & 11 & 2.7 \\
\hline 8. & Radiopacities & $\begin{array}{l}\text { Often-bright, } \\
\text { well-shaped structure }\end{array}$ & Greyscale & Patient & Dense foreign bodies & 10 & 2.5 \\
\hline 9. & $\begin{array}{l}\text { Silver thiosulphate } \\
\text { particles }\end{array}$ & $\begin{array}{l}\text { Dark particles imprinted } \\
\text { on radiographs }\end{array}$ & Dark & Processor & $\begin{array}{l}\text { Uncleaned rollers after } \\
\text { prolonged idleness }\end{array}$ & 9 & 2.2 \\
\hline 10. & Tattoos & Regular, aesthetic designs & Greyscale & Processor & $\begin{array}{l}\text { Developer-stained feed } \\
\text { tray as a result of pulling } \\
\text { film out from lead roller }\end{array}$ & 7 & 1.8 \\
\hline 11. & $\begin{array}{l}\text { Static electric } \\
\text { discharge }\end{array}$ & Tree-like design & Dark & Pre-processor & $\begin{array}{l}\text { Screen abrasion with } \\
\text { rough, dry material }\end{array}$ & 4 & 1.0 \\
\hline 12. & Grid lines & Parallel, grey stripes & Greyscale & procedure & $\begin{array}{l}\text { Immobile grid or wrong } \\
\text { surface of stationary grid }\end{array}$ & 3 & 0.8 \\
\hline
\end{tabular}


Table 2. Proposed classification of artefacts.

\begin{tabular}{|c|c|c|c|c|c|}
\hline S/no & $\begin{array}{l}\text { Proposed } \\
\text { classification }\end{array}$ & Description of classification & $\begin{array}{l}\text { Appearance } \\
\text { of artefacts }\end{array}$ & $\begin{array}{c}\text { Traditional } \\
\text { classification [3] [7] }\end{array}$ & $\begin{array}{c}\text { Traditional } \\
\text { classification [2] }\end{array}$ \\
\hline 1. & Packaging & $\begin{array}{l}\text { Transportation and storage-induced } \\
\text { artefacts }\end{array}$ & Dark & Processing-related & Plus-density \\
\hline 2. & Procedure & $\begin{array}{l}\text { Artefacts arising from manipulation } \\
\text { of patients, machine \& accessories }\end{array}$ & Greyscale & Technologist-related & Plus and minus density \\
\hline 3. & Patient & Artefacts from \& on patients & Greyscale & Patient-related & Plus and minus density \\
\hline 4. & Pre-processor & $\begin{array}{l}\text { Artefacts in-between exposure } \\
\text { \& processsing }\end{array}$ & Dark & Processing-related & Plus-density \\
\hline 5. & Processor & Processor-induced artefacts & Greyscale & Processing-related & Plus and minus density \\
\hline 6. & Post-processor & After-processing artefacts & Greyscale & Technologist-related & Minus-density \\
\hline
\end{tabular}

\section{Discussion}

Our work suggests a classification based on six stages of the radiographic process. The appearance of artefacts in each stage is also given to aid specific decoding of individual artefacts.

Our study which is a combination of earlier works is strong on mnemonics. We suggest that artefacts be re-classified into packaging, procedure, patient, pre-processor, processor and post-processor.

Packaging in our context involves artefacts induced in the film emulsion by suppliers as well as end-users who store the films before exposure. We see procedure as every manipulation of the patient, machine and accessories done by the Radiographer in carrying out the radiographic examination. We noted pre-processor as the time interval between the exposure of the film to X-Ray and feeding into the processor. Post-processor we acknowledge as everything that occurs as soon as the radiograph comes out processed from the processor.

We observed that artefacts appeared as either dark or greyscale. Artefacts from patients and post-processor were found to hover between white and light grey, described as greyscale while those from procedure and processor went from one extreme of dark to the other extreme of white. Packaging and pre-processor artefacts were however, always found to be dark. This is probably due to the activation of silver halide by pressure which added to the overall activation by radiation, thereby creating a higher density. Radiopacities and dirty intensifying screens produced whitish-grey artefacts. It is strongly suggestive of significantly attenuated radiation leading to diminished silver halide activation.

We also observed that pressure and visible light on films before and after exposure to radiation caused dark artefacts. But pressure had no effect after processing. Only abrasion with a rough surface caused scratches and these appeared greyish. We recommend that our proposed classification be adopted as it addresses the genesis of artefacts in the film as well as the concomitant appearances.

\section{References}

[1] Horton, K.M., Johnson, P.T. and Fishman, E.K. (2010) MDCT of the Abdomen: Common Misdiagnoses at a Busy Academic Center. American Journal of Roentgenology, 194, 660-667. http://dx.doi.org/10.2214/AJR.09.3280

[2] Akinola, R., Oluwarotimi, A., Jinadu, F., Akintomide, T., Soeze, P. and Asuquo, O. (2008) Artefacts in Mammography: A Three Year Experience in a New Teaching Hospital. The Internet Journal of Radiology, 8.

[3] Hogge, J.P., Palmer, C.H., Muller, C.C., Little, S.T., Smith, D.C., Fatouros, P.P. and de Paredes, E.S. (1999) Quality Assurance in Mammography: Artifact Analysis. RadioGraphics, 19, 503-522. http://dx.doi.org/10.1148/radiographics.19.2.g99mr13503

[4] Caesar, L.J., Schueler, B.A., Zink, F.E., Daly, T.R., Taubel, J.P. and Jorgenson, L.L. (2001) Artefacts Found in Computed Radiography. British Journal of Radiology, 74, 195-202. http://dx.doi.org/10.1259/bjr.74.878.740195

[5] Kirberger, R.M. and Roos, C.J. (1995) Radiographic Artifacts. Journal of South African Veterinary Association, 66, 85-94.

[6] Waaler, D. and Hoffman, B. (2010) Image Rejects/Retakes-Radiographic Challenges. Radiation Protection Dosimetry, 139, 375-379. http://dx.doi.org/10.1093/rpd/ncq032 
[7] Van Ongeval, C., Jacobs, J. and Bosmans, H. (2008) Artefacts in Digital Mammography. JBR, 91, $262-263$.

[8] Willis, C.E., Thompson, S.K. and Shepard, S.J. (2004) Artifacts and Misadventures in Digital Radiography. Applied Radiology, 33, 11-20. 
Scientific Research Publishing (SCIRP) is one of the largest Open Access journal publishers. It is currently publishing more than 200 open access, online, peer-reviewed journals covering a wide range of academic disciplines. SCIRP serves the worldwide academic communities and contributes to the progress and application of science with its publication.

Other selected journals from SCIRP are listed as below. Submit your manuscript to us via either submit@scirp.org or Online Submission Portal.
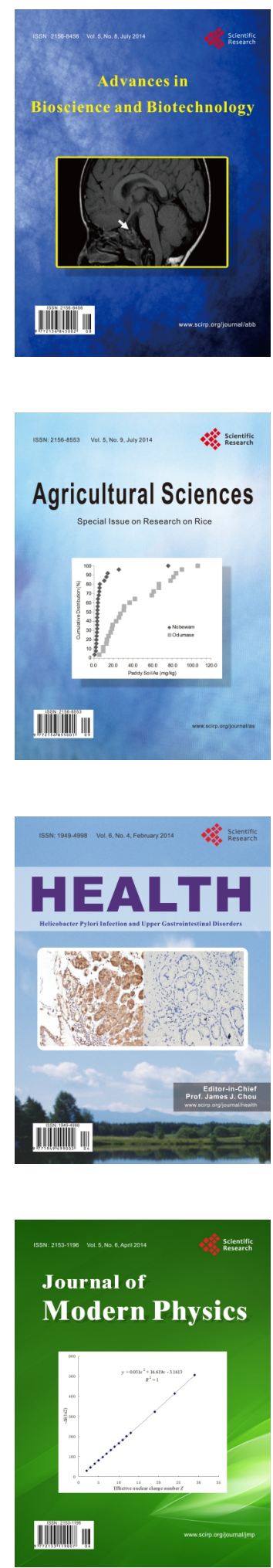
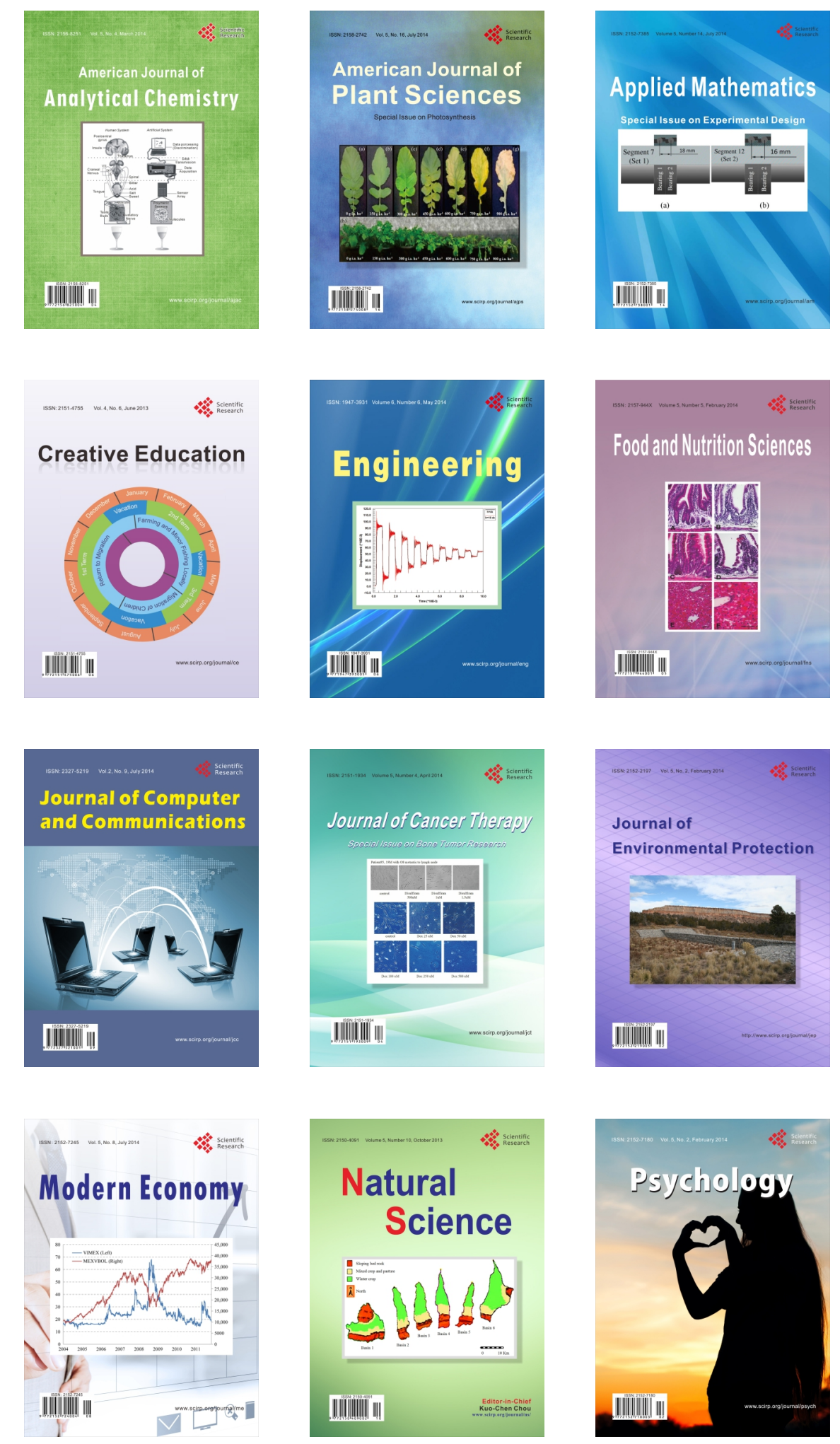